\title{
Lecturers' adoption to use the online Learning Management System (LMS): Empirical evidence from TAM2 model for Vietnam
}

\author{
Bui Thanh Khoa ${ }^{1}$, Nguyen Minh $\mathrm{Ha}^{2 *}$, Tran Viet Hoang Nguyen ${ }^{3}$, Nguyen Huu Bich ${ }^{4}$ \\ ${ }^{1}$ Industrial University of Ho Chi Minh City, Vietnam \\ ${ }^{2}$ Ho Chi Minh City Open University, Vietnam \\ ${ }^{3}$ Vietnam Microsoft Company Ltd., Vietnam \\ ${ }^{4}$ Ministry of Education and Training, Vietnam \\ *Corresponding author: ha.nm@ou.edu.vn
}

\begin{tabular}{ll}
\hline \multicolumn{1}{c}{ ARTICLE INFO } & \multicolumn{1}{c}{ ABSTRACT } \\
\hline $\begin{array}{l}\text { DOI: 10.46223/HCMCOUJS. } \\
\text { econ.en.10.1.216.2020 }\end{array}$ & $\begin{array}{l}\text { Online training has been a common form of training all over the } \\
\text { world for many years ago; however, it is only a side choice alongside } \\
\text { offline training. Not only students but also lecturers prefer offline } \\
\text { training to online training. However, in some cases of force majeure, } \\
\text { specifically the nCov-19 flu pandemic, online training is considered } \\
\text { the best way to teach. This study is based on the Technology }\end{array}$ \\
$\begin{array}{l}\text { Received: April } 20^{\text {th }}, 2020 \\
\text { Revised: April } 25^{\text {th }}, 2020\end{array}$ & $\begin{array}{l}\text { Acceptance Model 2 (TAM2) to learn about the lecturers' adoption } \\
\text { of using the learning management system (LMS) at universities in } \\
\text { Accepted: April } 27^{\text {th }}, 2020\end{array}$ \\
$\begin{array}{l}\text { Veywords: } \\
\text { objectives. Online group discussions, as well as online surveys, were } \\
\text { conducted to collect data to analyze and test the hypotheses as well } \\
\text { 2 (TAM2), lecturer, } \\
\text { Learning Management System } \\
\text { (LMS) }\end{array}$ & $\begin{array}{l}\text { as the theoretical model. The results of the study are similar to the } \\
\text { conclusions of TAM2. Thereby, the study proposes managerial } \\
\text { implications to improve the lecturers' adoption. }\end{array}$ \\
\hline
\end{tabular}

\section{Introduction}

The world is entering a knowledge economy in which the volume of information increases rapidly; the content of information is increasingly specialized and complex. Therefore, it requires lecturers at university to teach students how to self-learning and self-study. The Vietnamese Education Law (2005) also states that the method of higher education must attach importance to fostering self-study, self-learning and creating conditions for students to develop creative thinking, hone practical skills, participate in research, experiment, and practice. Currently, a powerful and highly effective way of learning is online learning, which is considered a very suitable training method to meet the requirements of society. This model has created profound changes in education, such as (1) making it easy for students to access and revise their knowledge, (2) breaking the time and space boundaries in training (Tarhini, Hone, \& Liu, 2014). This method will create a proactive environment where the lecturers act as a mentor or instructor (Meece \& Eccles, 2010).

Currently, most universities in Vietnam are implementing online training with many levels, and through multiple platforms, of which Moodle is a widely used platform not only in Vietnam but also in the world. Moodle, founded in 1999 by Martin Dougiamas, is an open-source learning management system (hereby LMS). In this study, the term online training management system is used for Moodle, a system being used by many universities in Vietnam. The LMS stands out as an education-oriented design for people working in the education field. The LMS supports to 
organize, arrange, and manage the training course. Besides, the LMS also has extensive functions to guide information mining and personal information management skills for lecturers and learners (Despotović-Zrakić, Marković, Bogdanović, Barać, \& Krčo, 2012).

Although the application of an online training system will enhance training effectiveness and allow universities' training programs to be uninterrupted in force majeure cases, i.e., nCov-19 flu pandemic. However, the use of this system is still limited to higher education institutions in Vietnam. According to a report of the Ministry of Education and Training, by the beginning of April 2020, the whole university education system currently has ninety-eight units that are holding online teaching. These institutes can be divided into three groups, including:

(1) Few universities have experienced the deployment of distance education and online training through their system or LMS;

(2) Some institutes have not yet an LMS but have begun to use an effective software to support online teaching and learning in real-time such as Zoom, Google Meet, Microsoft Team;

(3) The third group is of institutes that have neither implemented nor ready for organizing online training for regular students, only providing self-study documents.

Online teaching activities will not be widespread if users tend not to accept and do not know how to use and operate the system. Therefore, the deployment of online university training depends on the technology's readiness of students and lecturers. Besides the causes from the students, this limitation also comes from the lecturers, who directly participate in teaching. Therefore, lecturers and policymakers need to pay attention to factors affecting the faculty's adoption of the online training system, thereby contributing to improving the student learning experience and teaching skill of lecturers ( T. M. Nguyen, 2015; Tarhini et al., 2014).

At present, studies on the adoption of an online training management system are mainly focused on the use of the Technology Acceptance Model (hereby TAM) to analyze behavior (Opoku, Pobee, \& Okyireh, 2020; Sulaiman, Bali Mahomed, Hassan, \& Abd Rahman, 2019). This state partly contributes to understanding how the usefulness and ease of use of the LMS affect to the lecturers' intention to use; however, the drawback of TAM is that it does not yet identify user factors, which is the reason for the proposition of TAM2 (Chuttur, 2009). In addition, studies on the adoption of online training systems in Vietnam are still limited. Firstly, most Vietnam researches have contributed to the construction, operation, and evaluation of online training systems (H. T. Nguyen, 2019; T. D. P. Nguyen, 2011). Secondly, the UTAUT model is applied to evaluate online training (T. D. Nguyen, Nguyen, \& Cao, 2014). Thirdly, the research object of survey and evaluation is a student ( H. T. Nguyen, 2019; T. D. Nguyen et al., 2014).

Infectious disease pandemics have an outbreak, i.e., SARS in 2003, Ebola epidemic, or the nCov-19 pandemic at the beginning of 2020, the adoption to use the LMS became even more urgent at the request of the government and the needs of the society. Therefore, the study of the lecturers' adoption to use the LMS in higher education institutions is practical.

\section{Literature review}

\subsection{The theoretical model}

Theory of Reasoned Action (hereby TRA) explains the formation of human behavior (Ajzen \& Fishbein, 1975). Theory of Planned Behavior (hereby TPB) inherits TRA and incorporates behavioral control awareness factors to improve behavior prediction (Ajzen, 1985). However, the two theories only explain human behavior more generally in the common contexts of life. In response to technological change, Davis (1989) introduced the TAM model based on 
TRA and TPB with two factors that are perceived usefulness and perceived ease of use. The TAM model provides insight to predict systematic characteristics that affect the attitude and behavior of using information systems. TAM has become a universal model, applied and developed by many scientists for a long time. Venkatesh and Davis (2000) proposed the TAM2, which is based on TAM, or TAM3 was proposed by Venkatesh and Bala (2008).

The study is conducted in the context of higher education, with the study object is the adoption to use the LMS, and the survey object is the lecturers, who are white-collar workers with the capability to research and use systems more easily than others. Therefore, the study supposed that the usefulness of the LMS would be the main factor affecting the lecturers' adoption, especially in a situation where the social distancing applied to make direct communication with students more difficult. The perceived usefulness will allow lecturers and administrators in higher education institutions to design organizational interventions that would increase user adoption with new systems, i.e., the LMS. Therefore, the TAM2 model is proposed as a theoretical framework.

TAM2 combines subjective norms and visual criteria, which are aspects of related social aspects. These aspects help determine whether an individual will perceive the usefulness of a system and decide to adopt or reject this system. Besides, job relevance, output quality, result demonstrability, and perceived ease of use are a range of cognitive factors that determine perceived usefulness in the TAM2 model. The results imply that individuals will have a more positive attitude towards the usefulness of the system if it is easy to observe the difference between usage and positive results. Moreover, perceived ease of use checks if the system is easy to use and how easy it is. Venkatesh and Davis (2000) claim that TAM2 proposes that all cognitive tool processes positively influence perceived usefulness and, ultimately, an individual to adopt an information system. The TAM2 includes two-part, the first part is the TAM model with Perceived Usefulness, Perceived Ease of Use, and Adoption To Use; the second part is the out-technology constructs as the Subjective Norm, Lecturer's Image, Job Relevance, Output Quality, and Result Demonstrability. The theoretical model of this research is based on the TAM2 model and presented in Figure 1.

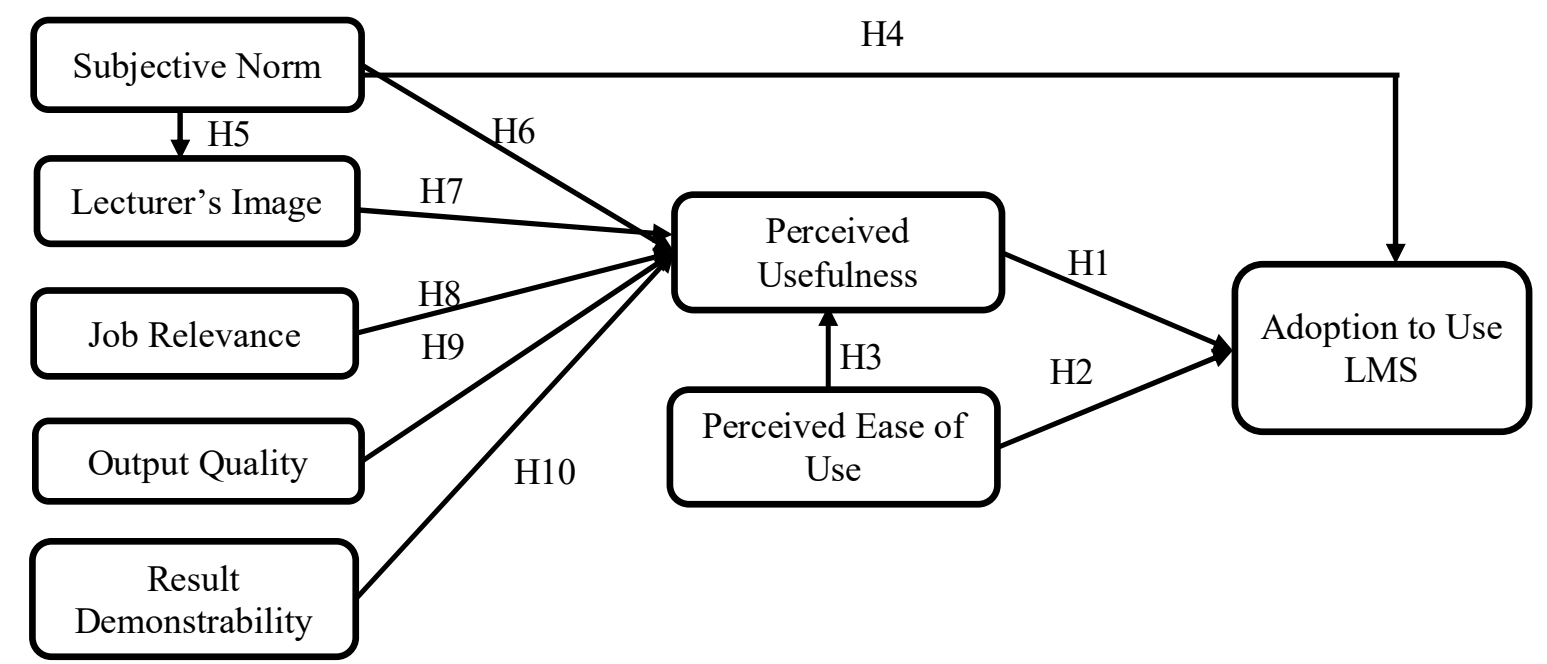

Figure 1. Theoretical model

\subsection{Research hypotheses}

Adoption to use a system is defined as the intention to use the system for the user's current job, or the intension to continue using the system in the future (Ajzen, 1991; Opoku et al., 2020). The act of accepting and using LMS is a concept that includes two aspects of "behavior" and "awareness". Acceptance to use is a real use of the online training system, and it is also a commitment to maintaining awareness and obligation to continue usage of the LMS service system. 
Perceived usefulness is the extent to which a person believes that using information technology or system can enhance one's work performance. In other words, users will have a positive attitude towards systems that benefit their work (Davis, 1989; Venkatesh, Morris, Davis, \& Davis, 2003). In the context of the epidemic, adopting the LMS is a solution for lecturers to be able to interact better with students during teaching and quality assurance. LMS will help lecturers share lecture content, assign work assignments to students, take multiple-choice tests to revise knowledge; thereby, increasing interaction with students. In addition, TAM2, just like TAM, refers to the concept of perceived ease of use, is the extent to which it is believed that a particular technology will not take much effort to learn how to use the system (Davis, 1989). In this case, the lecturers are highly qualified employees, who can use the Internet or read instruction; therefore, it is easier for them to learn how to use and operate the LMS.

Many studies have empirically revealed that perceived ease of use is significantly related to the adoption to use, both directly and indirectly, through its impact on perceived usefulness (Davis, Bagozzi, \& Warshaw, 1989). TAM2 retains perceived ease of use from TAM as a direct determinant of system usefulness. Also, if the lecturers understand that LMS can be used with less effort, they will find it useful and will be used in the lecture to a greater extent. From the experiences and researches of many previous researchers, this study found that the perceived usefulness and perceived ease of use of the LMS are considered as the standard prefixes leading to the adoption to use LMS in lectures (Segars \& Grover, 1998). Therefore, the following hypotheses are proposed:

\section{H1: The perceived usefulness has a positive impact on the adoption to use LMS of the lecturer}

H2: The perceived ease of use has a positive impact on the adoption to use LMS of the lecturer

H3: The perceived ease of use has a positive impact on the perceived usefulness of LMS

The subjective norm is defined as the awareness of a person that most people who are important to him think that he should or should not perform the behavior in a situation. Subjective norms affect the intention to use a system, whether that person likes to do it. Subjective norm has a significant influence on behavioral intent (Taylor \& Todd, 1995). Lin (2007) explained the behavior of the customers via TAM2 when they offer the service from the travel websites. It has been found that the beliefs of people who are that using new technology is considered to empower one's status in a social system. The image refers to the knowledge of an individual's group of influential people that a specific behavior should be performed because by doing such action, that individual can continually improve the quality of his internal work in the organization (Blau, 2017). If individuals perform acts that are expected by the group rules, then the performance of the entire group can also be enhanced; therefore, individuals can receive the support of the whole group and society (Pfeffer, 1982). In Vietnam, the lecturer is one of the occupations with a superior position or image in the mind of the entire community. If lecturers update their knowledge by using technology or practice to use the LMS technology in the lecture can make students and their parents, colleagues, and managers appreciate their capabilities. Besides, when a lecturer uses the LMS proficiently, they will receive attention from colleagues; then, this lecturer can be an example to many friends or colleagues who believe that the LMS should be used in case of need. Hence, the lecturer will most likely judge that LMS is useful for him/her. Thus, the research proposed the hypotheses:

H4: Subjective norm has a positive impact on the adoption to use LMS of the lecturer 


\section{H5: Subjective norm has a positive impact on the lecturer's image}

H6: Subjective norm has a positive impact on the perceived usefulness of LMS

H7: The lecturer's image has a positive impact on the perceived usefulness of LMS

Another structure mentioned in TAM2 is job relevance. Job relevance is a crucial component of a combination process in which potential users evaluate the effectiveness of using a specific system in their work. In TAM2, it is defined as a personal perception of the extent to which the target system applicable to a user's action. The users could improve their work efficiency if they have a good understanding of their work-related knowledge. It can be inferred that job relevance has a direct effect on perceived usefulness (Kieras \& Polson, 1985; Polson, 1987). If the LMS is related to teaching activities, it will become a useful tool to improve the teaching effectiveness of teachers. It makes perfect sense that LMS is a system programmed for educational purposes such as course management and student management, as well as enhancing interaction when a direct contact is an unavailable option. Therefore, the hypothesis $\mathrm{H} 8$ is proposed:

\section{H8: Job relevance has a positive impact on the perceived usefulness of LMS}

The output quality is defined as the extent to which an individual assesses the effectiveness of a new system. The output quality is the degree to which a new system is thought to be able to perform the required tasks (Lin, 2007). When users realize that a system contributes to their performance of functions, they will notice an improvement in work efficiency. Davis, Bagozzi, and Warshaw (1992) have shown experimentally that perceived output quality has a positive relationship with perceived usefulness. If consumers are satisfied with the quality of the site's products or services, they tend to consider the site as useful. The lecturers' usage of LMS in teaching will make interacting with students easier, thereby improving the quality of education; therefore, the lecturers will realize the output quality and evaluate the LMS as useful. From there, the study proposed the hypothesis:

\section{H9: Output quality has a positive impact on the perceived usefulness of LMS}

The tangibility of results when using innovative technology will directly affect usability (Moore \& Benbasat, 1991). Result Demonstrability means that users would perceive a system positively if the positive outputs were noticeable. The more easily-to-see benefits which a site can offer, the more useful it will be. Through the LMS, lecturers can provide lectures and exercises; lecturers can follow the student submission process; also, archive their scores and assignments is another advantage of the LMS. Therefore, the study proposes:

H10: Result Demonstrability has a positive impact on the perceived usefulness of LMS

\section{Research method and data}

\subsection{Research method}

This study applies technology acceptance theory 2 (TAM2), so it will be conducted through two stages with (1) qualitative research stage to adjust the scale, and (2) quantitative research stage to test research hypotheses and theoretical model. 


\section{Table 1}

The measurement scales

\begin{tabular}{|c|c|}
\hline Code & Item \\
\hline \multicolumn{2}{|r|}{ Subjective Norm (SN) } \\
\hline SN1 & Other lecturers think that I should use the LMS in lectures. \\
\hline SN2 & My supervisors in university think that I should use the LMS in lectures. \\
\hline \multicolumn{2}{|r|}{ Lecturer's Image } \\
\hline LI1 & I have more prestige than those who do not use the LMS in lectures. \\
\hline LI2 & I have a high profile when I adopt the LMS. \\
\hline LI3 & I become the status symbol in my university if I expert in the LMS. \\
\hline \multicolumn{2}{|r|}{ Job relevance } \\
\hline JR1 & The LMS is essential for my lecture at the university \\
\hline JR2 & The LMS is relevant for my lecture at the university \\
\hline \multicolumn{2}{|r|}{ Output Quality } \\
\hline OQ1 & The lecture quality which I get from the LMS is high. \\
\hline OQ2 & There is no problem with the lecture quality of the LMS's output when I adopt \\
\hline \multicolumn{2}{|r|}{ Result Demonstrability } \\
\hline RD1 & Telling others about the results of using the LMS is not difficult \\
\hline RD2 & I can assign easily the homework, the multiple-choice test for the student in LMS \\
\hline RD3 & I can store the examination of the student in LMS \\
\hline RD4 & I can send the presentation slide before the course for student via LMS \\
\hline \multicolumn{2}{|r|}{ Perceived Usefulness } \\
\hline PU1 & (I think) My performance in my lecture is improved by the adoption to use LMS. \\
\hline PU2 & (I think) My productivity is increased by the adoption to use LMS. \\
\hline PU3 & (I think) My lecture effectiveness is enhanced by the adoption to use LMS. \\
\hline PU4 & (I think) I find the LMS to be useful in my lecture. \\
\hline \multicolumn{2}{|r|}{ Perceived Ease of Use } \\
\hline PEOU1 & (I think) The LMS is clear and understandable to interact with the LMS. \\
\hline PEOU2 & (I think) There is not my mental effort to interact with the LMS. \\
\hline PEOU3 & (I think) The LMS to be easy to use in my lecture. \\
\hline PEOU4 & (I think) It is easy for me to use LMS for what I want. \\
\hline \multicolumn{2}{|r|}{ Adoption to Use LMS } \\
\hline ATU1a & Assuming I can use the LMS, I intend to use it for the lecture. \\
\hline ATU2a & Assuming I can use it to the LMS, I predict that I would use it for the lecture. \\
\hline ATU1b & After the first time, I want to continue using the LMS in a lecture next time \\
\hline ATU2b & I will continue to use the LMS in lecture \\
\hline
\end{tabular}

Source: The research's data analysis

Stage (1) is a qualitative study to adjust and add the items. Firstly, the research team will translate the original scale of Vankentesk and Davis (2000) including 23 items measuring eight 
research constructs, including Intention to Use (2 items), Perceived Usefulness (4), Perceived Ease of Use (4), Subjective Norm (2), Lecturer's Image (3), Job Relevance (2), Output Quality (2), Result Demonstrability (4). This qualitative research aims to test the homogeneity and comprehensiveness of items that measure research constructs.

An online focus group was held via Google Meet with 12 lecturers who used the LMS system at universities in Ho Chi Minh City, such as FPT University, Ho Chi Minh City Open University, University of Information Technology. The discussion lasted for 90 minutes, chaired by the authors. Discourse content is recorded, stored, and used to develop scale adjustments for quantitative surveys. The results of the discussion indicated that it was necessary to replace the intention to apply by adoption to use LMS and to develop two more items to measure the intention to continue using LMS. In addition, it is necessary to adjust the wording of items to be clear, easy to understand, and suitable for the context of LMS research in Vietnam. The results of the group discussion showed 25 items based on the analysis of Venkatesh and Davis (2000), of which the adoption to use LMS construct consisted of 4 items ( 2 items for those who intend to use for the first time - ATU1a, ATU2a, and two items for those who intend to continue using - ATU1b, ATU2b), and modify the content of items in Result Demonstrability scale for a specification. The twenty-five items are presented in Table 1.

After the qualitative research, the quantitative was done to test ten hypotheses above and the theoretical model. Quantitative analysis was conducted through an online survey using Google Form from January 2020 to March 2020.

Table 2

The sample characteristics

\begin{tabular}{|l|l|c|c|}
\hline \multicolumn{1}{|c|}{ Characteristics } & N & \% \\
\hline \multirow{4}{*}{ Status } & have used & 502 & 51.86 \\
\cline { 2 - 4 } & never use before & 466 & 48.14 \\
\hline \multirow{5}{*}{ Aender } & Male & 487 & 50.31 \\
\cline { 2 - 4 } & Female & 481 & 49.69 \\
\hline \multirow{5}{*}{ Education level } & $24-28$ & 326 & 33.68 \\
\cline { 2 - 4 } & $29-32$ & 269 & 27.79 \\
\cline { 2 - 4 } & $33-45$ & 287 & 29.65 \\
\cline { 2 - 4 } & Above 45 & 86 & 8.88 \\
\cline { 2 - 4 } & Master & 716 & 73.97 \\
\cline { 2 - 4 } & Associate Professor & 191 & 19.73 \\
\cline { 2 - 4 } & Professor & 39 & 4.03 \\
\hline \multirow{5}{*}{ University } & University of Information Technology (UIT) & 22 & 2.27 \\
\cline { 2 - 4 } & Ho Chi Minh City University of Technology (HUTECH) & 137 & 14.15 \\
\cline { 2 - 4 } & Ho Chi Minh City Open University (OU) & 70 & 5.17 \\
\cline { 2 - 4 } & Industrial University of Ho Chi Minh City (IUH) & 136 & 14.05 \\
\cline { 2 - 4 } & University of Finance and Marketing (UFM) & 11.88 \\
\hline
\end{tabular}




\begin{tabular}{|l|l|c|c|}
\hline \multicolumn{1}{|c|}{ Characteristics } & N & \% \\
\hline & Ha Noi Open University (HOU) & 137 & 14.15 \\
\cline { 2 - 4 } & National Economics University (NEU) & 111 & 11.47 \\
\cline { 2 - 4 } & FPT University (FU) & 50 & 5.17 \\
\cline { 2 - 4 } & Da Nang University & 90 & 9.30 \\
\cline { 2 - 4 } & Duy Tan University & 72 & 7.44 \\
\hline
\end{tabular}

Source: The research's data analysis

The participants are the lecturers who lecture at universities in Vietnam. Due to time and financial constraints, the study carried out sampling with a non-probability method with the snowball method of combining with quota method in 3 regions in Southern (50\%), Central (20\%), and Northern $(30 \%)$. The online questionnaire was distributed via email to lecturers connected to the research team; then, these lecturers used the snowball method to pass it on to other respondents until the initial set rate was reached. Finally, the number of respondents to the online questionnaire was 980, including 968 valid data for quantitative analysis such as reliability test, validity test, hypothesis test. The sample size and characteristics are described in Table 2 . The data is processed by SPSS and Smart-PLS software 3.2.7.

\section{Result}

\subsection{The reliability and validity assessment}

In the first step, this study will assess the reliability of scale by Cronbach's Alpha (CA); and the convergent validity, as well as the discriminant validity via the criteria including, Composite Reliability (CR), the Average Variance Extracted (AVE), and Heterotrait-Monotrait Ratio (HTMT). The criteria for assessment are followed by the research of Hair, Hult, Ringle, \& Sarstedt (2016) as Table 3.

\section{Table 3}

The summary of criteria for assessing the reliability and validity

\begin{tabular}{|l|l|l|}
\hline \multicolumn{1}{|c|}{ Assessment } & \multicolumn{1}{c|}{ Criterion } & \multicolumn{1}{c|}{ Threshold } \\
\hline \multirow{2}{*}{ The reliability of the scale } & Cronbach's alpha (CA) & Equal to or more than 0.7 \\
\hline \multirow{3}{*}{ Convergent validity } & Outer loading, & Equal or more than 0.708 \\
\cline { 2 - 3 } & Composite Reliability (CR) & Equal or more than 0.7 \\
\cline { 2 - 3 } & Average Variance Extracted (AVE) & Equal or more than 0.5 \\
\hline \multirow{2}{*}{ Discriminant validity } & $\begin{array}{l}\text { Heterotrait-Monotrait Ratio (HTMT) } \\
\text { between two constructs }\end{array}$ & Lower than 0.85 \\
\hline
\end{tabular}

Source: Data analysis result of the research

Table 4 showed the HTMT value between each pair of the construct in the study. The largest of HTMT is 0.817 (JR and LI), which is less than 0.85. From this result, all constructs in the research archived the discriminant validity. 
Table 4

The HTMT value

\begin{tabular}{|c|c|c|c|c|c|c|c|}
\hline & ATU & JR & LI & OQ & PEOU & PU & RD \\
\hline JR & 0.584 & & & & & & \\
\hline LI & 0.593 & 0.817 & & & & & \\
\hline OQ & 0.553 & 0.524 & 0.535 & & & & \\
\hline PEOU & 0.655 & 0.501 & 0.487 & 0.451 & & & \\
\hline PU & 0.697 & 0.785 & 0.779 & 0.721 & 0.666 & & \\
\hline RD & 0.623 & 0.517 & 0.501 & 0.382 & 0.535 & 0.692 & \\
\hline SN & 0.681 & 0.642 & 0.618 & 0.717 & 0.588 & 0.797 & 0.551 \\
\hline
\end{tabular}

Source: Data analysis result of the research

The result of the evaluation in Table 5 pointed out that the minimum CA coefficient is 0.764, which is more than 0.7; hence, all constructs in the research archived the reliability. Moreover, the lowest CR of all constructs in the study is 0.893 , which is more than 0.7 . The minimum AVE is 0.677 , which is higher than 0.5. Moreover, the minimum outer loading of each construct in the research is more than 0.708 . Consequently, the constructs got convergent validity.

Table 5

The outer loadings, CA, CR, AVE

\begin{tabular}{|c|c|c|c|c|c|c|c|c|c|c|c|}
\hline & ATU & JR & LI & OQ & PEOU & $\mathbf{P U}$ & RD & SN & CA & CR & AVE \\
\hline ATU1 & 0.954 & & & & & & & & \multirow{2}{*}{0.89} & \multirow{2}{*}{0.95} & \multirow{2}{*}{0.9} \\
\hline ATU2 & 0.945 & & & & & & & & & & \\
\hline JL1 & & 0.943 & & & & & & & \multirow{2}{*}{0.88} & \multirow{2}{*}{0.94} & \multirow{2}{*}{0.89} \\
\hline JL2 & & 0.944 & & & & & & & & & \\
\hline LI1 & & & 0.915 & & & & & & \multirow{3}{*}{0.89} & \multirow{3}{*}{0.93} & \multirow{3}{*}{0.82} \\
\hline LI2 & & & 0.895 & & & & & & & & \\
\hline LI3 & & & 0.911 & & & & & & & & \\
\hline OQ1 & & & & 0.944 & & & & & \multirow{2}{*}{0.88} & \multirow{2}{*}{0.94} & \multirow{2}{*}{0.89} \\
\hline OQ2 & & & & 0.947 & & & & & & & \\
\hline PEOU1 & & & & & 0.894 & & & & \multirow{4}{*}{0.91} & \multirow{4}{*}{0.94} & \multirow{4}{*}{0.8} \\
\hline PEOU2 & & & & & 0.877 & & & & & & \\
\hline PEOU3 & & & & & 0.929 & & & & & & \\
\hline PEOU4 & & & & & 0.865 & & & & & & \\
\hline PU1 & & & & & & 0.897 & & & \multirow{4}{*}{0.85} & \multirow{4}{*}{0.9} & \multirow{4}{*}{0.7} \\
\hline PU2 & & & & & & 0.743 & & & & & \\
\hline PU3 & & & & & & 0.836 & & & & & \\
\hline PU4 & & & & & & 0.853 & & & & & \\
\hline
\end{tabular}




\begin{tabular}{|c|c|c|c|c|c|c|c|c|c|c|c|}
\hline & ATU & JR & LI & OQ & PEOU & PU & RD & SN & CA & CR & AVE \\
\hline RD1 & & & & & & & 0.817 & & & & \\
RD2 & & & & & & & 0.838 & & \multirow{2}{*}{0.84} & 0.89 & 0.68 \\
\hline RD3 & & & & & & & 0.838 & & & & \\
\hline RD4 & & & & & & & 0.796 & & & & \\
\hline SN1 & & & & & & & & 0.888 & \multirow{2}{*}{0.76} & 0.89 & 0.81 \\
\hline SN2 & & & & & & & & 0.911 & & & \\
\hline
\end{tabular}

Source: Data analysis result of the research

\subsection{The hypotheses and theoretical model assessment}

In this part, the research will test ten hypotheses and theoretical models. Hair et al. (2016) suggested the process to verify the Partial Least Squares Structural Equation Modeling (PLSSEM), which has the bootstrap procedure with 5000 random subsamples, including 05 steps below in Table 6.

Table 6

The levels in the assessment of the theoretical model and hypotheses

\begin{tabular}{|c|l|c|l|}
\hline Step & \multicolumn{1}{|c|}{ Assessment } & Criterion & \multicolumn{1}{|c|}{ The threshold } \\
\hline 1 & Collinearity & VIF value & Less than 5 \\
\hline 2 & Path Coefficient & $\mathrm{p}$-value & Less than 0.05 \\
\hline 3 & $\begin{array}{l}\text { Coefficient of } \\
\text { Determination }\end{array}$ & $\mathrm{R}^{2}$ value & $\begin{array}{l}0.75,0.50, \text { or } 0.25, \text { respectively, described as the } \\
\text { substantial, moderate, or weak explanation of the } \\
\text { change of dependent construct under the impact of the } \\
\text { independent construct. }\end{array}$ \\
\hline 4 & Effect Size & $\mathrm{f}^{2}$ value & $\begin{array}{l}0.02,0.15, \text { and 0.35, respectively, represent small, } \\
\text { medium, and large effects the exogenous latent variable }\end{array}$ \\
\hline 5 & Predictive Relevance & $\mathrm{Q}^{2}$ value & Larger than 0 \\
\hline
\end{tabular}

Source: Data analysis result of the research

Table 7

The result of VIF, $\mathrm{R}^{2}, \mathrm{f}^{2}$, and $\mathrm{Q}^{2}$

\begin{tabular}{|c|c|c|c|c|c|c|c|c|}
\hline & \multicolumn{3}{|c|}{ VIF } & \multirow[b]{2}{*}{$\mathbf{R}^{2}$} & \multicolumn{3}{|c|}{$\mathbf{f}^{2}$} & \multirow[b]{2}{*}{$\mathbf{Q}^{2}$} \\
\hline & ATU & LI & $\mathrm{PU}$ & & ATU & LI & PU & \\
\hline ATU & & & & 0.485 & & & & 0.415 \\
\hline JR & & & 2.337 & & & & 0.055 & \\
\hline LI & & & 2.303 & 0.263 & & & 0.063 & 0.204 \\
\hline $\mathrm{OQ}$ & & & 1.659 & & & & 0.108 & \\
\hline PEOU & 1.579 & & 1.555 & & 0.123 & & 0.053 & \\
\hline $\mathrm{PU}$ & 2.052 & & & 0.712 & 0.069 & & & 0.464 \\
\hline $\mathrm{RD}$ & & & 1.481 & & & & 0.1 & \\
\hline SN & 1.772 & 1 & 1.947 & & 0.06 & 0.357 & 0.034 & \\
\hline
\end{tabular}

Source: Data analysis result of the research 
The result of VIF, $\mathrm{R}^{2}, \mathrm{f}^{2}$, and $\mathrm{Q}^{2}$ in Table 7 pointed out that all the VIF value in Table 7 is smaller than 5; hence, the constructs in the research model do not have collinearity with the others. The ATU, LI, and PU have been explained by $48.5 \%, 26.3 \%$, and $71.2 \%$ by the change of independent variables. Although the $\mathrm{R}^{2}$ of $\mathrm{LI}$ is $26.3 \%$, it can be accepted in this research, due to $\mathrm{R}^{2}$ value can be allowed with 0.2 in behavioral science (Hair et al., 2016).

The SN has the large effect size on the LI (0.357); JR, LI, OQ, PEOU, RD, and SN have the small effect size on PU with $\mathrm{f}^{2}$ value, respectively, are $0.055,0.063,0.108,0.053,0.1$, and 0.034; finally, PEOU, PU, and SN have the small effect size on ATU with $\mathrm{f}^{2}$ value, respectively, are $0.123,0.069$, and 0.06 . Table 7 also pointed out all $\mathrm{Q}^{2}$ value are more than $0\left(\mathrm{Q}^{2} \mathrm{ATU}=0.415\right.$, $\mathrm{Q}^{2} \mathrm{LI}=0.204$; and $\left.\mathrm{Q}^{2} \mathrm{PU}=0.464\right)$.

The p-value of the valid path coefficient in Table 8 is less than 0.05 . The path coefficients in Table 8 archived significantly with the $p$-value is less than 0.000 .

\section{Table 8}

The result of PLS-SEM

\begin{tabular}{|l|c|c|c|c|c|c|}
\hline & Beta & STDEV & T Statistics & P Values & H & Result \\
\hline PU -> ATU & 0.271 & 0.045 & 6.024 & 0.000 & H1 & Accepted \\
\hline PEOU -> ATU & 0.316 & 0.046 & 6.819 & 0.000 & H2 & Accepted \\
\hline PEOU -> PU & 0.154 & 0.023 & 6.813 & 0.000 & H3 & Accepted \\
\hline SN -> ATU & 0.235 & 0.036 & 6.538 & 0.000 & H4 & Accepted \\
\hline SN -> LI & 0.513 & 0.038 & 13.413 & 0.000 & H5 & Accepted \\
\hline SN -> PU & 0.137 & 0.026 & 5.242 & 0.000 & H6 & Accepted \\
\hline LI -> PU & 0.204 & 0.026 & 7.892 & 0.000 & H7 & Accepted \\
\hline JR -> PU & 0.193 & 0.024 & 8.041 & 0.000 & H8 & Accepted \\
\hline OQ -> PU & 0.227 & 0.022 & 10.254 & 0.000 & H9 & Accepted \\
\hline RD -> PU & 0.206 & 0.023 & 9.066 & 0.000 & H10 & Accepted \\
\hline
\end{tabular}

Source: Data analysis result of the research

\section{Discussion}

The results of the research have made a positive contribution to assess the TAM2 in the adoption to use the learning management system in the Vietnam Universities. The study presented the following conclusions:

Similar to the results of the TAM model, hypotheses H1, H2, H3 are accepted with $99 \%$ confidence. Research shows that perceiving usefulness has a positive impact on technology adoption $(\mathrm{Beta}=0.271, \mathrm{p}$-value $=0.000)$. This result is consistent with the results of the empirical model of Fathema and Sutton (2013). The use of LMS in lectures will bring many benefits for lecturers, which leads to the intention to use in the future or continue to use the LMS. Moreover, perceived ease of use has the strongest impact on LMS acceptance of lecturers at universities (Beta $=0.316, \mathrm{p}$-value $=0.000$ ). The shift to teaching technology, especially in urgent situations such as the nCov-19 pandemic, can be a challenge for faculty members. For teachers who have never used LMS before, the ease-of-use feature is an important criterion for learning to adopt LMS. Moreover, 
the easy-to-use feature is also a positive premise for the faculty's useful awareness for LMS (Beta $=0.154, \mathrm{p}$-value $=0.000$ ). This result supports the conclusion of Bousbahi and Alrazgan (2015) if reducing the time to learn how to use LMS, as well as reducing operational errors, lecturers consider it a useful feature of the system.

Subjective norm is the key component of TRA and TPB; it is a direct determinant of behavioral intent and also a key element of the theoretical background of TAM2 (Ajzen \& Fishbein, 1975; Ajzen, 1985; Venkatesh \& Davis, 2000). The hypotheses concerning the subjective norm in this study, include H4, H5, and H6, are accepted with a 99\% confidence level. Firstly, the subjective norm positively influences the teacher's adoption of LMS (Beta $=0.235$; $\mathrm{p}$ value $=0.000$ ). Currently, the use of LMS in teaching is applied at the department level, or the university level; therefore, other instructors using the system will affect an individual's adoption. In addition, the rector board or department deans are aware of the importance of using LMS in training; therefore, even mandatory incentives from the top and middle manager level will take place. Therefore, the subjective norm has a direct impact on the LMS adoption of lecturers. Besides, subjective norm also positively affect the image of lecturers (Beta $=0.513$; and $\mathrm{p}$-value $=0.000$ ). In the context of the lecture at universities, it can be inferred that if people who are important to faculty such as colleagues, dean or vice-dean, or students think that the LMS system is needed to improve performance, increase interaction with students, and overcome epidemic difficulties, lecturers may consider LMS to be a useful medium for using in lecture (BaleghiZadeh, Ayub, Mahmud, \& Daud, 2014; Cigdem \& Topcu, 2015).

A special feature of TAM2 compared to TAM is that it determines the factors affecting the perceived usefulness of system users (Venter, van Rensburg, \& Davis, 2012). This result is also confirmed through empirical results with the acceptance of hypotheses from H6 to H10, with a $99 \%$ confidence level. In particular, the output quality is considered as the most positive positive impact on the perceived usefulness of the LMS (Beta $=0.227$, p-value $=0.000)$, followed by result demonstrability $($ Beta $=0.206, p$-value $=0.000)$, lecturer's image $($ Beta $=0.204$, p-value $=0.000)$, job relevance $($ Beta $=0.193, \mathrm{p}$-value $=0.000)$, and finally the subjective norm $($ Beta $=0.137, \mathrm{p}$ value $=0.000$ ). As mentioned above, the use of the LMS is only considered useful when this system brings the output quality as well as get the result demonstrability in the teaching process of lecturers. An online lecture, which is no face to face with students, will get more difficult when there is no interaction with students. Therefore, LMS helps teachers improve the quality of teaching, as well as interact with online classes better through assigning essay assignments, testing via multiple-choice, providing presentation slides before lectures, enrolling students online, assigning homework, or storing the exam of students. Nextly, LMS is a system designed and developed exclusively for training. Therefore, the application of LMS into lecture is an activity associated with the teaching process, and will also enhance the professional image of lecturers to students and colleagues.

\section{Conclusion and research future}

The development of science and technology, especially the advent of the Internet, has changed many areas of society, including education. Higher education is a tertiary education in all training systems of countries around the world. Hence, the adoption of technology becomes necessary for students who are capable of working in businesses or the government. Moreover, unexpected events, such as the nCov-19 epidemic that took place, have placed higher education institutions in the context of having to choose for students to stay at home in a long-term period, or learning online. Therefore, lecturers will play an essential role in the process of receiving and 
adopting technology in training. Based on the qualitative and quantitative research, this research confirmed the TAM2 in the context of LMS adoption in Vietnam and pointed out the positive relationship between all constructs in the theoretical model. The result included (1) The lecturers' adoption to use the LMS is impacted by the perceived usefulness, perceived ease of use, and subjective norm, (2) subjective norm has a positive impact on the lecturers' image, (3) the perceived usefulness of the LMS is the result of the perceived ease of use, subjective norm, lecturers' image, job relevance, output quality, and result in demonstrability.

Therefore, to enhance lecturers' adoption to use the LMS in the lecture, the study proposes some managerial implications. Firstly, the universities need to build an easy-to-use LMS system, such as translate into Vietnamese the functions in the LMS, have the training sessions, develop manuals for using tasks in the system, add responsible experts in charge of LMS system to answer, and handle situations during operation. In addition, it is necessary to improve the usefulness of the system by having regulations on minimum standards for the use of LMS when teaching, to recognize and reward lecturer who use the system effectively in the teaching process through competitions, or emulation movements at the department level and university level. Moreover, there are clear criteria for evaluating the quality of the output after the instructor's adoption,i.e., compare student scores, survey student satisfaction as well as before and after.

Despite many efforts, this study still has some limitations. Firstly, the study applied only the TAM2 model to explain the teacher's acceptance of the use of LMS. This limitation has not fully clarified the premises leading to the adoption of a system. Therefore, further studies may combine TAM2 and UTAUT (The Unified Theory of Acceptance and Use of Technology), or TAM2 and IDT (Innovation Diffusion Theory). Secondly, the subjects assessed in the study merely the adoption to use the Moodle system, so the future researches can possible to expand the online learning, which uses the real-time technology like Zoom, Google Meet, combined with the application of LMS in teaching to create more complete and meaningful results.

\section{References}

Ajzen, I. (1985). From intentions to actions: A theory of planned behavior. In J. Kuhl \& J. Beckmann (Eds.), Action control. SSSP Springer series in social psychology. Berlin, Germany: Springer. doi:10.1007/978-3-642-69746-3_2

Ajzen, I. (1991). The theory of planned behavior. Organizational Behavior and Human Decision Processes, 50(2), 179-211. doi:10.1016/0749-5978(91)90020-T

Ajzen, I., \& Fishbein, M. (1975). Belief, attitude, intention and behavior: An introduction to theory and research. Reading, MA: Addison-Wesley.

Baleghi-Zadeh, S., Ayub, A. F. M., Mahmud, R., \& Daud, S. M. (2014). The influence of subjective norm on intention to use of learning management system among Malaysian higher education students. Paper presented at the AIP Conference Proceedings.

Blau, P. (2017). Exchange and power in social life. London, UK: Routledge.

Bousbahi, F., \& Alrazgan, M. S. (2015). Investigating IT faculty resistance to learning management system adoption using latent variables in an acceptance technology model. The Scientific World Journal, 2015, 1-11. doi:10.1155/2015/375651

Chuttur, M. Y. (2009). Overview of the technology acceptance model: Origins, developments and future directions. Working Papers on Information Systems, 9(37), 9-37. 
Cigdem, H., \& Topcu, A. (2015). Predictors of instructors'behavioral intention to use learning management system: A Turkish vocational college example. Computers in Human Behavior, 52, 22-28. doi:10.1016/j.chb.2015.05.049

Davis, F. D. (1989). Perceived usefulness, perceived ease of use, and user acceptance of information technology. MIS Quarterly, 13(3), 319-340. doi:10.2307/249008

Davis, F. D., Bagozzi, R. P., \& Warshaw, P. R. (1989). User acceptance of computer technology: A comparison of two theoretical models. Management Science, 35(8), 982-1003. doi: $10.1287 / \mathrm{mnsc} .35 .8 .982$

Davis, F. D., Bagozzi, R. P., \& Warshaw, P. R. (1992). Extrinsic and intrinsic motivation to use computers in the workplace. Journal of Applied Social Psychology, 22(14), 1111-1132.

Despotović-Zrakić, M., Marković, A., Bogdanović, Z., Barać, D., \& Krčo, S. (2012). Providing adaptivity in Moodle LMS courses. Journal of Educational Technology \& Society, 15(1), 326-338.

Fathema, N., \& Sutton, K. L. (2013). Factors influencing faculty members Learning Management Systems adoption behavior: An analysis using the Technology Acceptance Model. International Journal of Trends in Economics Management \& Technology (IJTEMT), 2(6), 20-28.

Hair, J. F., Hult, G. T. M., Ringle, C., \& Sarstedt, M. (2016). A primer on Partial Least Squares Structural Equation Modeling (PLS-SEM). London, UK: Sage Publications.

Kieras, D., \& Polson, P. G. (1985). An approach to the formal analysis of user complexity. International Journal of Man-Machine Studies, 22(4), 365-394. doi:10.1016/S00207373(85)80045-6

Lin, C. F. (2007). A study of customer intention and its antecedents on e-commerce of travel industry (Unpublished master's thesis). National Dong Hwa University, Taiwan.

Meece, J. L., \& Eccles, J. S. (2010). Learner-centered practices: Providing the context for positive learner development, motivation, and achievement. In J. L. Meece \& J. S. Eccles (Eds.), Handbook of research on schools, schooling and human development (pp. 78-92). London, UK: Routledge.

Moore, G. C., \& Benbasat, I. (1991). Development of an instrument to measure the perceptions of adopting an information technology innovation. Information Systems Research, 2(3), $192-$ 222. doi:1047-7047/91/0203/0192/\$01.25

Nguyen, H. T. (2019). Nghiên cứu các yếu tố tác động đến sụ hài lòng của học viên tham gia khóa hoc đào tạo trục tuyến ở các trường đại học khu vục TP. HCM [The factors affecting the satisfaction of students taking online training courses at Ho Chi Minh City Universities]. (Master Dissertation, University of Economics Ho Chi Minh City). Retrieved March 11, 2020, from http://digital.lib.ueh.edu.vn/handle/UEH/58920

Nguyen, T. D., Nguyen, D. T., \& Cao, T. H. (2014). Sự chấp nhận và sử dụng đào tạo trực tuyến trên điện toán đám mây [Online training's acceptance and usage on cloud computing]. Science and Technology Development Journal, 17(3Q), 71-87. 
Nguyen, T. D. P. (2011). Thiết kế và xây dựng hệ thống đào tạo trục tuyến tại truờng trung cấp nghề Quảng Nam [Designing and building online training system at Quang Nam vocational secondary school] (Unpublished master's thesis). The University of Da Nang, Vietnam.

Nguyen, T. M. (2015). Nghiên cứu mô hình và đề xuất giải pháp đào tạo trực tuyến hỗ trợ một số môn học, ngành học tại Trường Đại học Thái Nguyên [Thai Nguyen University's research model and some proposals to support online training subjects]. Journal of Science and Technology, 133(3), 167-172.

Nguyen, V. H. (2019). Học viện KH\&CN: Cần sớm triển khai đào tạo trực tuyến [Vietnam Academy of Science and Technology: The necessity of the implementation online training]. Vietnam Journal of Science, Technology and Engineering, 3, 46-47.

Opoku, D., Pobee, F., \& Okyireh, R. O. (2020). Determinants of e-learning system adoption among ghanaian university lecturers: An application of information system success and technology acceptance models. Humanities, 5(1), 151-168. doi:10.20448/801.51.151.168

Pfeffer, J. (1982). Organizations and organization theory. Boston, MA: Pitman Boston.

Polson, P. G. (1987). A quantitative theory of human-computer interaction. In J. M. Carroll (Ed.), Interfacing thought: Cognitive aspects of human-computer interaction (pp. 184-235). Cambridge, MS: Bradford Books/ MIT Press.

Segars, A. H., \& Grover, V. (1998). Strategic information systems planning success: An investigation of the construct and its measurement. MIS Quarterly, 22(2), 139-163. doi: $10.2307 / 249393$

Sulaiman, T. T., Bali Mahomed, A. S., Hassan, M., \& Abd Rahman, A. (2019). Factors affecting university lecturers' adoption of Learning Management System (LMS) in Kurdistan region of Iraq: A conceptual framework. International Journal of Psychosocial Rehabilitation, 23(2), 860-871. doi:10.37200/IJPR/V23I2/PR190336

Tarhini, A., Hone, K., \& Liu, X. (2014). The effects of individual differences on e-learning users' behaviour in developing countries: A structural equation model. Computers in Human Behavior, 41, 153-163. doi:10.1016/j.chb.2014.09.020

Taylor, S., \& Todd, P. A. (1995). Understanding information technology usage: A test of competing models. Information Systems Research, 6(2), 144-176.

Venkatesh, V., \& Bala, H. (2008). Technology acceptance model 3 and a research agenda on interventions. Decision Sciences, 39(2), 273-315. doi:10.1111/j.1540-5915.2008.00192.x

Venkatesh, V., \& Davis, F. D. (2000). A theoretical extension of the technology acceptance model: Four longitudinal field studies. Management Science, 46(2), 186-204. doi:10.1287/mnsc.46.2.186.11926

Venkatesh, V., Morris, M. G., Davis, G. B., \& Davis, F. D. (2003). User acceptance of information technology: Toward a unified view. MIS Quarterly, 27(3), 425-478. doi:10.2307/30036540

Venter, P., van Rensburg, M. J., \& Davis, A. (2012). Drivers of learning management system use in a South African open and distance learning institution. Australasian Journal of Educational Technology, 28(2), 183-198. doi:10.14742/ajet.868

WTO. (2005). Vietnamese education law. Retrieved November 20, 2019, from https://www.wto.org/english/thewto_e/acc_e/vnm_e/WTACCVNM43_LEG_14.pdf 